* Corresponding author

Phone +421556022469

E-mail address: roberthunady@tuke.sk

(Ing. Róbert Huňady, PhD.)

Article information

Article history: AMS-Volume16-No.1-00140-12

Received 4 February 2012

Accepted 25 February 2012

\section{Operational Vibration Analysis of Railway Transport Complex}

\author{
František Trebuňa ${ }^{\text {a* }}$, František Šimčák ${ }^{\text {a }}$, Róbert Huňady ${ }^{\mathrm{a}}$
}

a Department of Applied Mechanics and Mechatronics, Faculty of Mechanical Engineering, Letná 9, 04200 Košice, Slovak Republic

\section{BIOGRAPHICAL NOTES}

Dr.h.c. mult. prof. Ing. František Trebuňa, CSc. is a professor of applied mechanics, Head of the Department of Applied Mechanics and Mechatronics and Dean of the Faculty of Mechanical Engineering. He is author of 10 monographs, 12 university textbook, special book publications, 12 university notebooks and more than 300 publications in journals and conference proceedings at Slovakia abroad. He is author of important projects and engineering works. He received several prizes at home and abroad. He received three titles Doctor Honoris Causa (DHC) including two from foreign universities for the development of applied mechanics and mechatronics.

prof. Ing. František Šimčák, CSc. he is a professor of applied mechanics, Deputy head of the Department of Applied Mechanics and Mechatronics. He is author of 4 monographs, 7 university textbooks, 6 university notebooks and more than 200 publications in journals and conference proceedings at Slovakia and abroad. He received several prizes due to his scientific results.

Ing. Róbert Huňady, Ph.D. he received M.S. degree in mechanical engineering from Technical University of Košice, Slovakia in 2007. In 2009, he attended EC Marie Curie Training Program SIMVIA2 at Czech Technical University of Prague, Czech republic. He finished his doctoral study in study field Applied mechanics in Faculty of mechanical engineering at Technical University of Košice, Slovakia in 2010. Since 2010 he has been working as lecture at Department of Applied Mechanics and Mechatronics at Technical University of Košice, Slovakia. His professional activity is oriented into the area of modern optical methods of experimental mechanics such as high-speed digital image correlation, electronic speckle pattern interferometry and laser doppler vibrometry. He is author or co-author of more than 30 journals, conference papers and works aimed particularly at experimental modal and vibration analysis.

\section{KEY WORDS}

Transport complex, container, vibration analysis

\section{ABSTRACT}

Packages for transporting radioactive materials have to meet requirement of normal and accident transport conditions. On the basis of methodology of experimental verification packages for transport of radioactive materials elaborated by authors were realized extensive tests of containers. In the paper is described modal and vibration analysis of transport complex during its transportation.

\section{Introduction}

Transport containers serve for manipulation and transport with spent nuclear fuel from reactors of nuclear power stations. During the certification of packages (containers) for transporting radioactive materials is necessary to provide analyses that they 
meet requirements of Regulations of Nuclear Regulatory Authority of the Slovak Republic - UJD SR No.57/2006 Z.z. for normal and failure conditions of transport [1]. On the workplace of authors was recently realized safety verification of containers by analytical and numerical methods [2]. Because of fact that above-mentioned verification recommends for the assessment of container safety experimental methods, the authors had elaborated methodology for such a test of nuclear waste packages $[3,4]$. One part of extensive experimental analysis $[5,6]$ was a modal analysis and analysis of vibration of real transport complex during its moving.

According to Supplement No. 1 of Regulation No. 57/2006, Part II., the consignment have to withstand any accelerations, vibrations, or resonances that can arose under conditions presumable during normal transport without decreasing of tightness of closure mechanisms in different parts of package or without violation of its integrity. From this reason has been accomplished modal analysis and analysis of vibration of system container - wagon, during its movement with prescribed velocity, starting, breaking as well as movement through twists and locations, where mechanical vibration of system could occur [7]. Container (Fig. 1) is positioned during the transport on special railway wagon (Fig. 2). For the transport on the carrying wagon are on the body of container welded 4 supporting (carrying) surfaces. The container is fixed to wagon by fitted bolts and 2 though holes on every supporting surface. Selected transport conditions and technical parameters of transport complex are max. velocity of loaded coach 100 $\mathrm{km} / \mathrm{h}$, weight of container $68 \mathrm{t}$, weight of wagon $35 \mathrm{t}$, max. loading capacity of wagon $85 \mathrm{t}$.

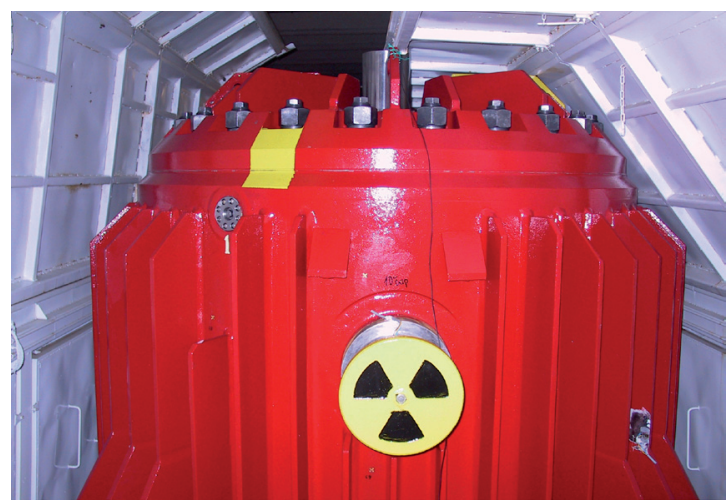

Fig. 1: Container for transport of spent nuclear fuel.

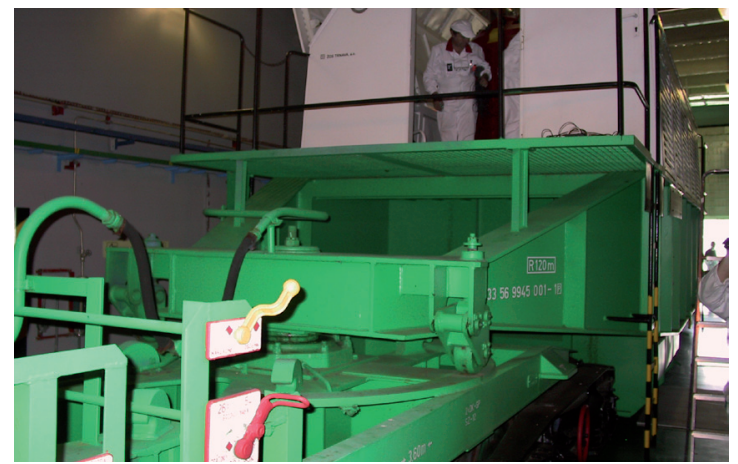

Fig. 2: Transport complex with container.

\section{Causes of transport complex vibration}

There are several sources of vibration in road and railway transport complexes [8 - 10]. The most important sources of excited vibrations that can occur during movement of transport complex are:

\section{- Interaction of steel wheels of undercarriage of} wagon during their rolling on rails

Vibration is caused by bumpiness (corrugation) of contact surface on rail heads (Fig. 3), or by roughness of contact surface resulting from damaged wheels.
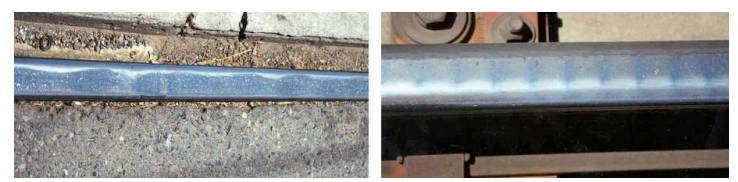

Fig. 3: Bumpiness of contact surface on rail head.

\section{- Impacts of wheels}

The impacts of wheels occur during run through the rail joints as result of gaps between rails or due to their non-coaxially. The same effect arises during run through rail switches (Fig. 4). In case of wheel damage (Fig. 5), where the flat surfaces on the wheel occur, the periodic impact influences results to excited vibration.

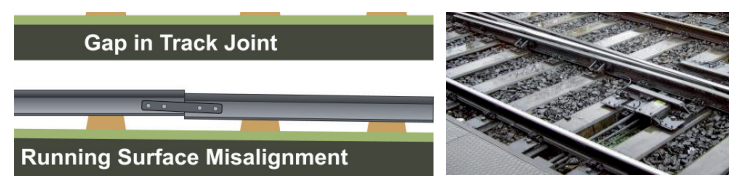

Fig. 4: Discontinuity of railway track.
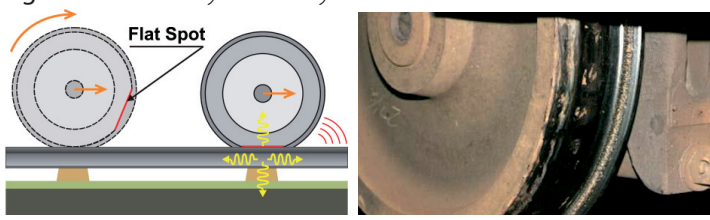

Fig. 5: Damage of wagon wheel. 


\section{- Immediate character of run}

The excitation shakes can occur also during starting, breaking and running through bends, which is accompanied by noticeable sound effect.

\section{Causes of transport complex vibration}

Modal analysis of mechanical systems can be realized by analytical, numerical or experimental methods of mechanics $[7,11,12]$.

Modal analysis of carrying part of wagon bridge was realized for two positions of three-axis acceleration sensor Brüel \& Kjær 4506B. Sensor S1 was positioned on a lid of container (Fig. 6a) and sensor S2 on a frame of undercarriage above pan of wagon bearing (Fig. 6b). Locations of sensors allow gaining information about transmission of vibration excitation during movement of complex at the second stage of measurement (see section 4).

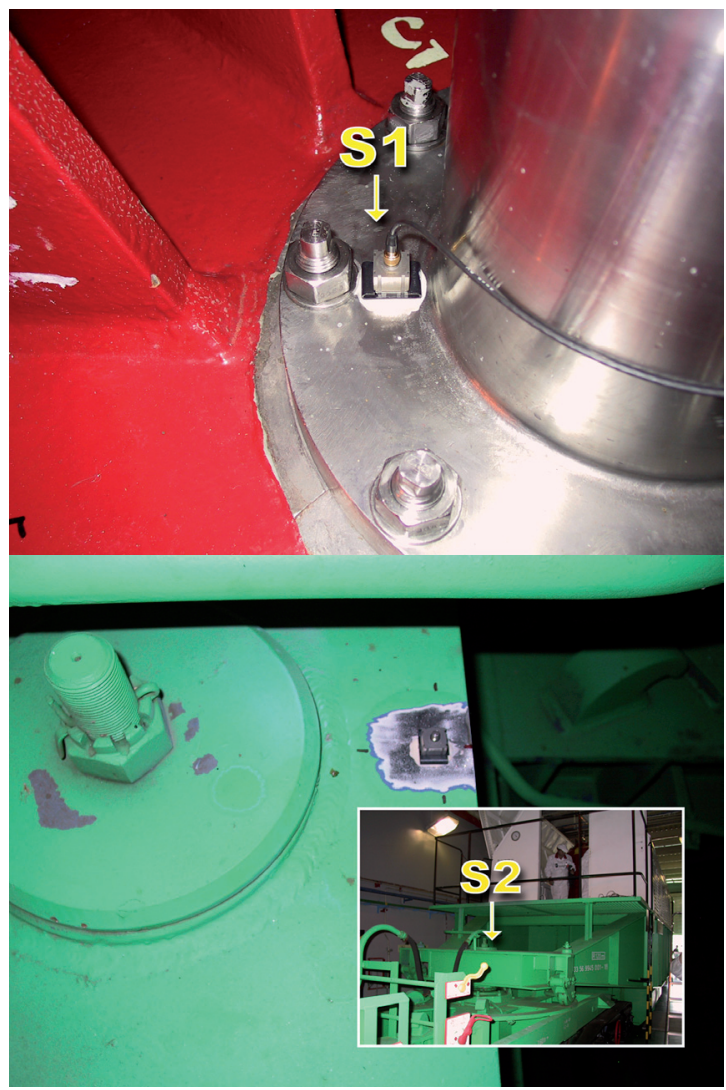

Fig. 6: a) Location of sensor S1 on lid of container, b) location of sensor 52 on the frame of undercarriage over bearing shell of wagon.

Table 1: Eigenfrequencies of transport complex.
The locations of hammer impact were chosen in such a way that the longitudinal and transversal symmetry of wagon has been exploited. There were chosen 9 locations for excitation by impact hammer. The locations were the same for both sensors (S1 and S2). Acceleration sensors S1 and S2 had axis $x$ in vertical direction, axis y was oriented perpendicular to axis of wagon and axis $z$ was identical with wagon's axis. For excitation was used impact hammer Brüel \& Kjær model 8210. For the measurement and its evaluation has been used platform Pulse produced by company Brüel \& Kjær.

Functions of frequency transfer measured for individual positions of excitation were processed in program Pulse Reflex. Software algorithms using function CMIF (Complex Mode Indicator Function) has been used for estimation of eigenshapes and eigenfrequencies. The eigenfrequencies determined by this procedure on the basis of analysis of stability diagrams are given in Table 1. It have to be mentioned that results of modal parameter measurement in which sensor $\$ 2$ was used, are identical with those gained by sensor $\mathrm{S} 1$.

\section{Operational vibration analysis of transport complex}

Measurement of operational vibration of transport complex during its movement was realized on railway road of length approximately $3600 \mathrm{~m}$. The road was divided to 5 sections (see Table 2) with considerably different characteristics of driving. In section No. 1 were recorded vibrations during starting of complex and during its movement through railway switches of railway station. Section No. 2 is characterized by driving through right bend. Section No. 3 is a straight road on the beginning of which is a railway bridge above road communication. Section No. 4 is left bended. In the section 5 that can be considered as straight road, the complex was stopped, accelerated and halting at the end of section. Maximum velocity of complex during measurement was $40 \mathrm{~km} / \mathrm{h}$, which corresponds to value received from operator.

For the measurement of vibration deflections were used three-component acceleration sensors Bruel\&Kjaer 4506B, applied in locations S1 and S2. The sensors were connected to measurement system Bruel\&Kjaer PULSE 3560 that records time-de-

\begin{tabular}{|l|l|l|l|l|l|l|l|l|l|l|}
\hline Frequency [Hz] & 4.33 & 13.99 & 35.37 & 44.37 & 74.15 & 81.37 & 98.54 & 120.2 & 435.9 & 696.7 \\
\hline
\end{tabular}


pendent charts of acceleration deflections to the hard disc of notebook. Measurement apparatus was supplied from portable electro-generator. In order to receive more precise analysis, time-dependent charts at individual sections were further divided into smaller time intervals. As the aim was to assess massiveness of vibration, the acceleration charts were transformed by function of frequency weighting $1 / j \omega$, while the received frequency spectrum of maximum velocities for given sections were filtered to frequency range from $2 \mathrm{~Hz}$ to $1 \mathrm{kHz}$, in accordance with Standard STN ISO 10816-1. Frequency spectra of maximum velocity amplitudes and its maximal effective values determined from signals S1 and S2 are for each section given in Fig. 7 - 12. Appropriate choice of frequency range allows reading frequen- cies at the highest amplitudes of velocity.

Table 2: Lengths and short description of road sections.

\begin{tabular}{|c|c|c|}
\hline Section number & Section length & $\begin{array}{l}\text { Description of } \\
\text { section }\end{array}$ \\
\hline 1 & $800 \mathrm{~m}$ & $\begin{array}{l}\text { Movement from } \\
\text { station - typically } \\
\text { crossing several } \\
\text { railway switches. }\end{array}$ \\
\hline 2 & $400 \mathrm{~m}$ & Right twist. \\
\hline 3 & $600 \mathrm{~m}$ & $\begin{array}{l}\text { Relatively straight } \\
\text { road. }\end{array}$ \\
\hline 4 & $150 \mathrm{~m}$ & Left twist. \\
\hline 5 & $1650 m$ & $\begin{array}{l}\text { Relatively straight } \\
\text { road. }\end{array}$ \\
\hline
\end{tabular}

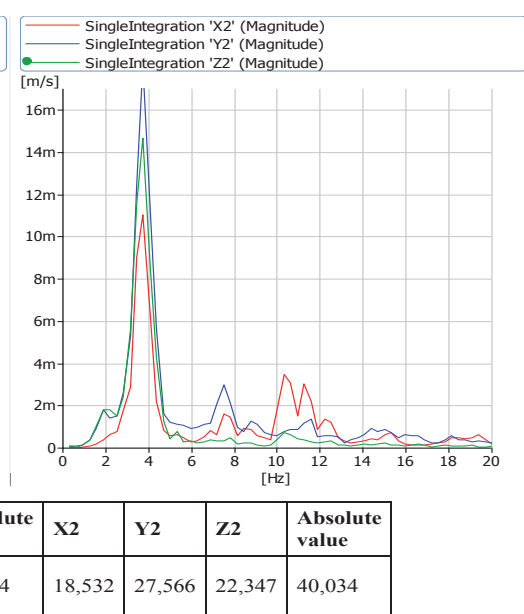

Fig. 7: Frequency spectra of maximum velocities and its effective values: Section no. 1 - acceleration through railway switches.
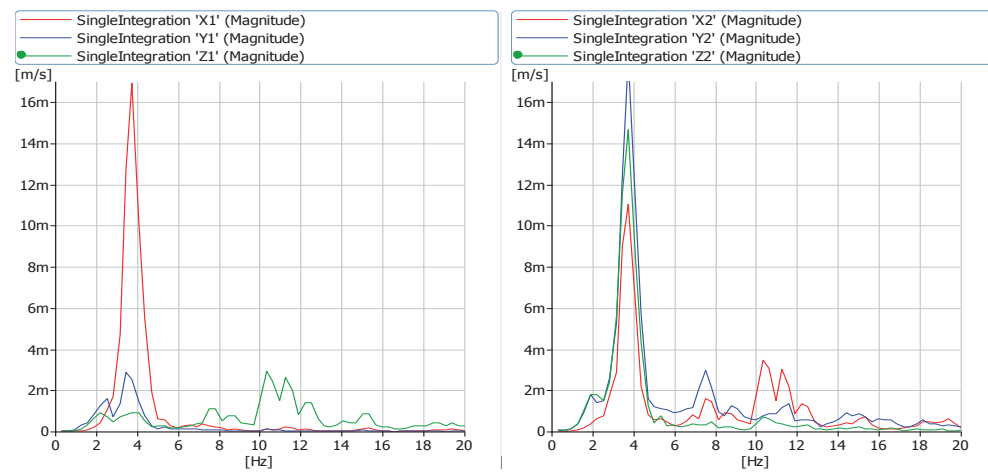

\begin{tabular}{|l|l|l|l|l|l|l|l|l|}
\hline & $\mathbf{X 1}$ & $\mathbf{Y 1}$ & $\mathbf{Z 1}$ & $\begin{array}{l}\text { Absolute } \\
\text { value }\end{array}$ & $\mathbf{X 2}$ & $\mathbf{Y 2}$ & $\mathbf{Z 2}$ & $\begin{array}{l}\text { Absolute } \\
\text { value }\end{array}$ \\
\hline $\begin{array}{l}\mathbf{v}_{\text {er }} \\
\text { [mm/s] }\end{array}$ & 24,826 & 5,11 & 7,218 & 26,354 & 18,532 & 27,566 & 22,347 & 40,034 \\
\hline
\end{tabular}

Fig. 8: Frequency spectra of maximum velocities and its effective values: Section No. 2 - right twist. 

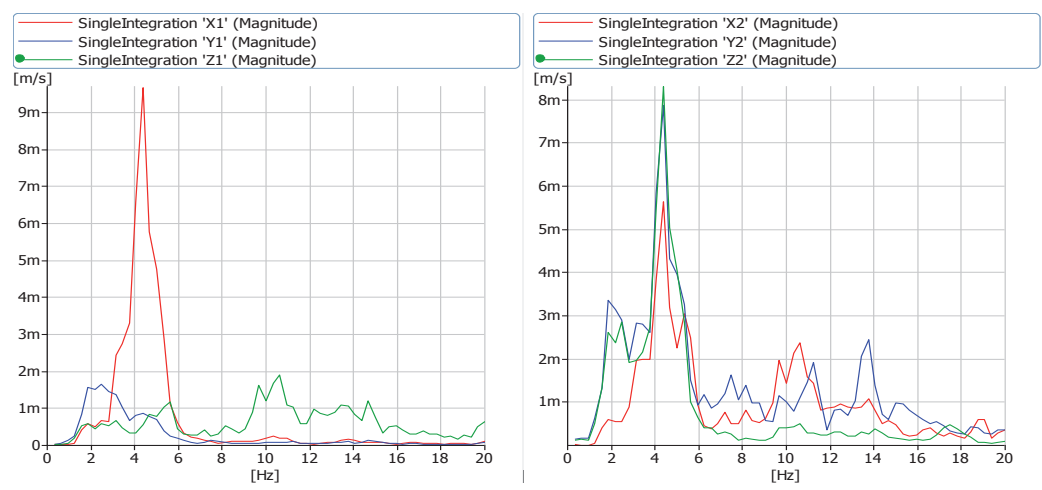

\begin{tabular}{|l|l|l|l|l|l|l|l|l|}
\hline & $\mathbf{X 1}$ & $\mathbf{Y 1}$ & $\mathbf{Z 1}$ & $\begin{array}{l}\text { Absolute } \\
\text { value }\end{array}$ & $\mathbf{X 2}$ & $\mathbf{Y 2}$ & $\mathbf{Z 2}$ & $\begin{array}{l}\text { Absolute } \\
\text { value }\end{array}$ \\
\hline $\mathbf{V}_{\text {ef }}[\mathbf{m m} / \mathbf{s}]$ & 15,164 & 4,138 & 6,067 & 16,849 & 12,434 & 16,445 & 14,117 & 24,993 \\
\hline
\end{tabular}

Fig. 9: Frequency spectra of maximum velocities and its effective values: Section No. 3 -straight.
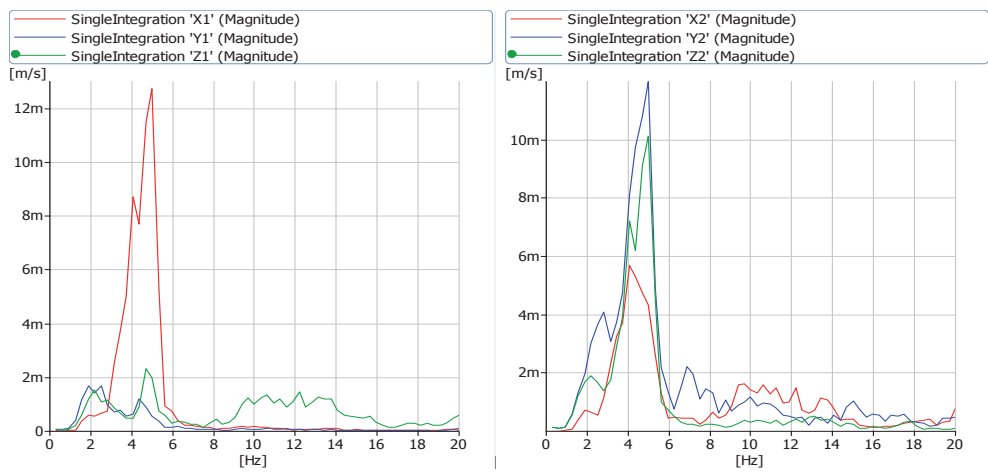

\begin{tabular}{|l|l|l|l|l|l|l|l|l|}
\hline & $\mathbf{X 1}$ & $\mathbf{Y 1}$ & $\mathbf{Z 1}$ & $\begin{array}{l}\text { Absolute } \\
\text { value }\end{array}$ & $\mathbf{X 2}$ & $\mathbf{Y 2}$ & $\mathbf{Z 2}$ & $\begin{array}{l}\text { Absolute } \\
\text { value }\end{array}$ \\
\hline $\mathbf{v}_{\text {ef }}[\mathbf{m m} / \mathbf{s}]$ & 22,512 & 3,893 & 6,848 & 23,850 & 13,975 & 24,663 & 18,579 & 33,893 \\
\hline
\end{tabular}

Fig. 10: Frequency spectra of maximum velocities and its effective values: Section No. 4 - left twist.
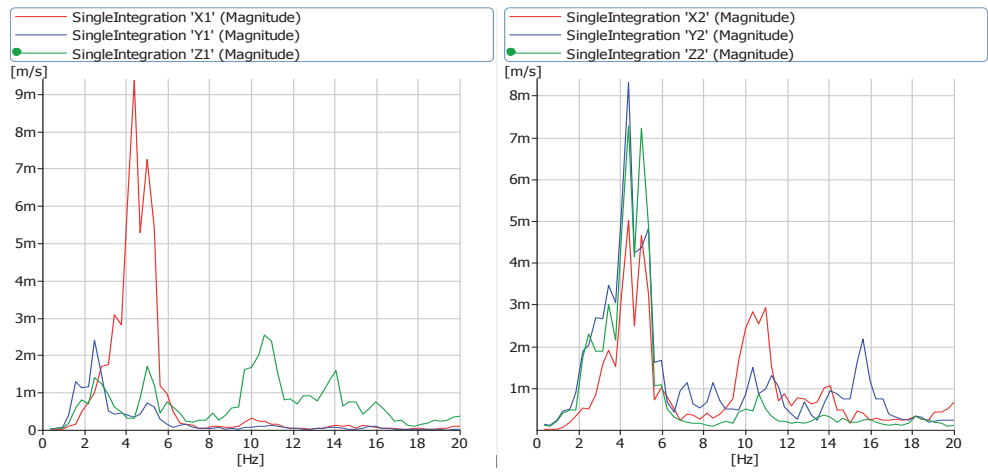

\begin{tabular}{|l|l|l|l|l|l|l|l|l|}
\hline & $\mathbf{X 1}$ & $\mathbf{Y 1}$ & $\mathbf{Z 1}$ & $\begin{array}{l}\text { Absolute } \\
\text { value }\end{array}$ & $\mathbf{X 2}$ & $\mathbf{Y 2}$ & $\mathbf{Z 2}$ & $\begin{array}{l}\text { Absolute } \\
\text { value }\end{array}$ \\
\hline $\mathbf{V}_{\text {ef }}[\mathbf{m m} / \mathbf{s}]$ & 16,217 & 3,904 & 7,523 & 18,298 & 12,769 & 15,994 & 14,438 & 25,046 \\
\hline
\end{tabular}

Fig. 11: Frequency spectra of maximum velocities and its effective values: Section No. 5 - movement. 

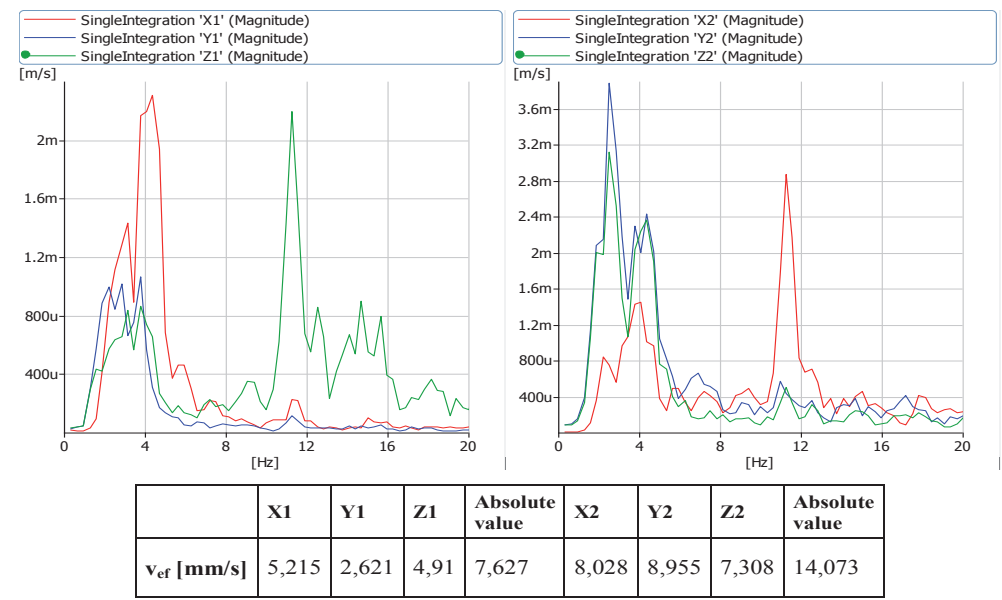

Fig. 12: Frequency spectra of maximum velocities and its effective values: Section No. 5 - deceleration on straight road.
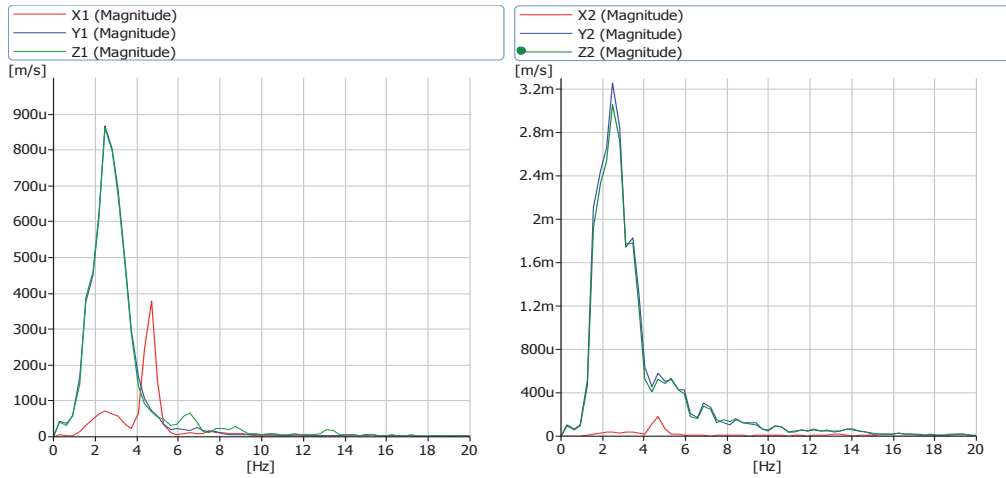

Fig. 13: Frequency spectrum of maximum amplitudes of complex vibration velocity during standstill of wagon measured by sensors $S 1$ and S2.
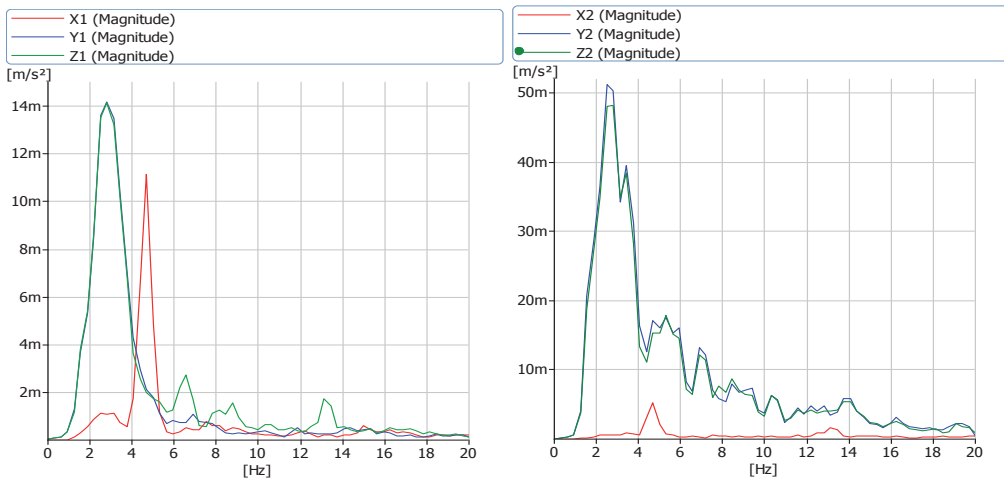

Fig. 14: Frequency spectrum of maximum amplitudes of complex vibration acceleration during standstill of wagon measured by sensors S1 and S2.

From operational vibration analysis of transport complex accomplished during its moving results that maximum effective vibration velocity was
$40 \mathrm{~mm} / \mathrm{s}$. This velocity was reached during acceleration through railway switches at the first section of road. 
In order to determine excitation effect of locomotive motor to vibration of transport complex as well as for elimination of influence of voltage generator, measurement of frequency spectrum of maximum vibration velocities of unmoving transport complex with working motor of locomotive and voltage generator has been accomplished. In Fig. 13 and Fig. 14 are depicted frequency spectra of maximum velocities and accelerations of vibration in locations of sensors S1 and S2 in directions $x, y, z$.

From graphs in Fig.13 and Fig.14 results that the biggest amplitudes of velocities are in frequency range 2.5 to $2.8 \mathrm{~Hz}$. These amplitudes can be registered also on charts of vibration velocities of transport complex during its movement.

\section{Conclusions}

From the results of operational vibration analysis of transport complex can be concluded that vibration velocity magnitudes mainly depend on the type of railway road and of transport conditions. The biggest amplitudes of vibration velocity during movement were reached at the range frequency $3.8-5.0 \mathrm{~Hz}$ which correspond to eigenfrequency $4.342 \mathrm{~Hz}$. Maximum allowable velocity $100 \mathrm{~km} / \mathrm{h}$ of transport complex can be, on the basis of modal and vibration analysis, considered to be suitable for transport. At the same time it is recommended to over cross the velocity $42-43 \mathrm{~km} / \mathrm{h}$ as fast as possible, because the excitation of system at this velocity is near frequency $4.3 \mathrm{~Hz}$. The other eigenfrequencies that result from analysis are not important for the technique of transport and accordingly no attention is given to them. According to Standard STN ISO 10816-6 „Mechanical vibration of machines on nonrotating parts", Addendum A, Table A.1 and for level of vibration massiveness 28 , for machines with classification numbers 5,6 and 7 , such an equipment is suitable for long time operation.

It has to be mentioned that during assessment of vibration massiveness, it was considered that absolute value of effective velocity is result of vector addition of effective velocity components in direction of axes $x, y, z$. Maximum value of such velocity was $40 \mathrm{~mm} / \mathrm{s}$. The machines with diesel motors with power crossing $100 \mathrm{~kW}$ and classified at level 6 and 7 can work under this velocity without limits.

\section{Acknowledgement}

The authors would like to express their gratitude to Scientific Grant Agency VEGA MŠ SR for the support of this work under Project No. 1/0289/11 and Project No. 1/0937/12

\section{References}

[1] Vyhláška č.57/2006, Z.z., ÚJD SR ktorou sa ustanovujú podrobnosti o požiadavkách pri preprave rádioaktívnych materiálov, zo dňa 12.1.2006

[2] Trebuňa, F. a kol.: Výpočtové overenie kontajnera v súlade s vyhláškou ÚJD SR č. 57/2006 Z.z (§ 7). Záverečná správa, SjF TU Košice, 2008

[3] Trebuňa, F. et al.: Metodika experimentálneho overenia stavu prepravného kontajnera na vyhoreté jadrové palivo, Záverečná správa, SjF TU Košice, 2008

[4] Trebuňa, F. et al.: Metodika typových meraní a skúšok vrátane overenia zostatkovej životnosti na transportných kontajneroch, Záverečná správa, SjF TU Košice, 2011

[5] Trebuňa, F. et al.: Overenie zostatkovej životnosti transportného kontajnera, Záverečná správa, SjF TU Košice, 2011

[6] Trebuňa, F. et al.: Typové merania a skúšky transportného kontajnera, Záverečná správa, SjF TU Košice, 2011

[7] Trebuňa, F., Šimčák, F.: Príručka experimentálnej mechaniky, 1. vydanie - Košice: SjF TU, 2007, 1526 s., ISBN 970-80-8073816-7

[8] Thompson D.: Railway noise and vibration: mechanisms, modelling and means, Elsevier, 2009, ISBN-13: 978-0-08045147-3

[9] Towers, D. A.: Rail transit noise and vibration, Harris Miller Miller \& Hanson Inc., 2008

[10] Žiaran, S.: Znižovanie kmitania a hluku v priemysle, STU Bratislava, 2006

[11] Elesztős, P., Écsi, L.: Parametrical Study of free Vibration and plastic Collapse of a Clamped beam. Acta Mechanica Slovaca, Vol. 14, No. 4, 2010, pp. 58-63, ISSN 1335-2393

[12] Vavro, J., Vavro J. jr., Handrik, M.: Numeric Analysis of the Eigenfrequencies of the Ductile Cast Iron with the Spheroidal Shape of graphite. Acta Mechanica Slovaca, Vol. 14, No. 4, 2010, pp. 64-73, ISSN 1335-2393 


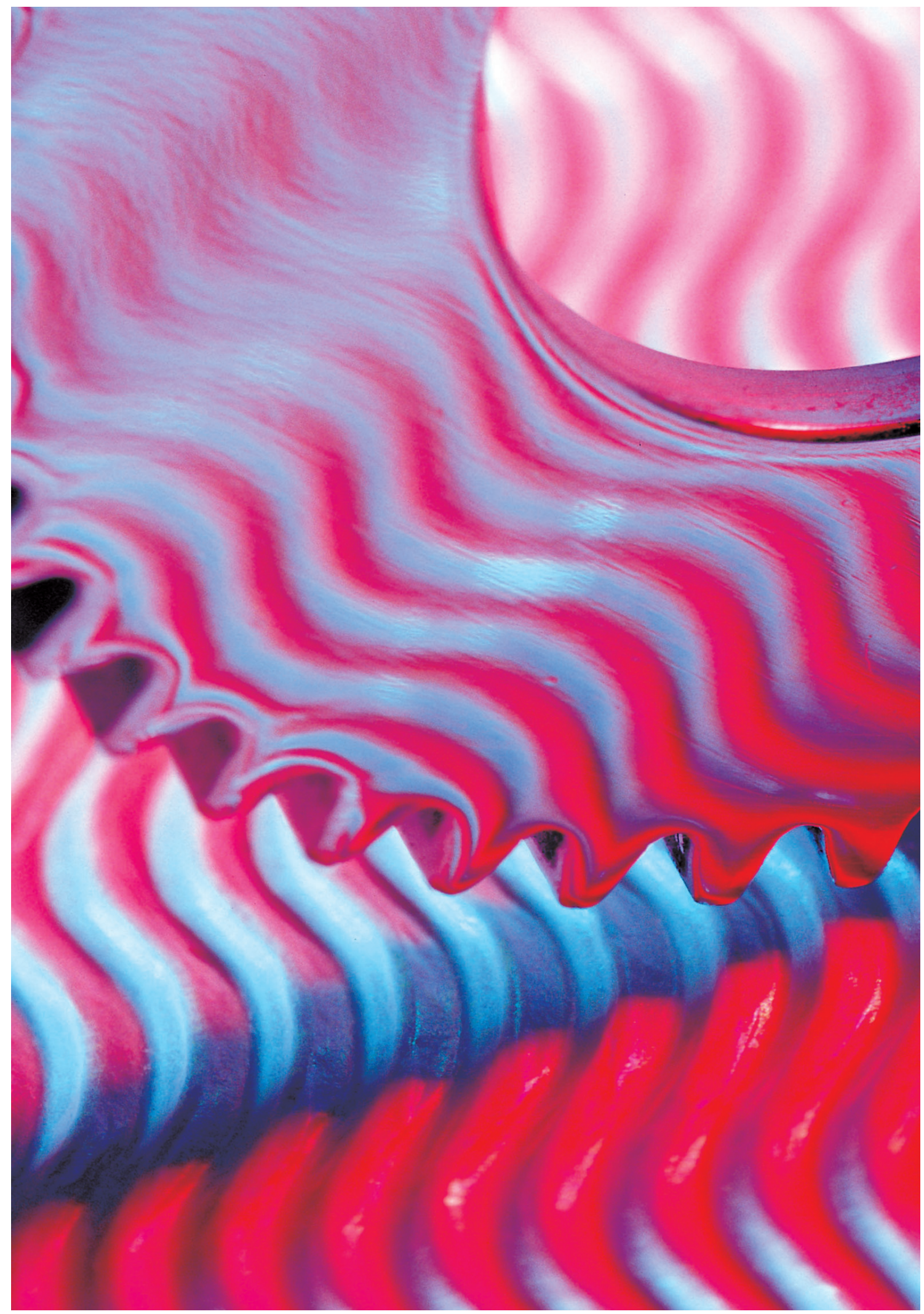

